\title{
Zinc Finger Protein 40
}

National Cancer Institute

\section{Source}

National Cancer Institute. Zinc Finger Protein 40. NCI Thesaurus. Code C150020.

Zinc finger protein 40 (2718 aa, $\sim 297 \mathrm{kDa}$ ) is encoded by the human HIVEP1 gene. This protein plays a role in the regulation of viral and cellular gene expression. 